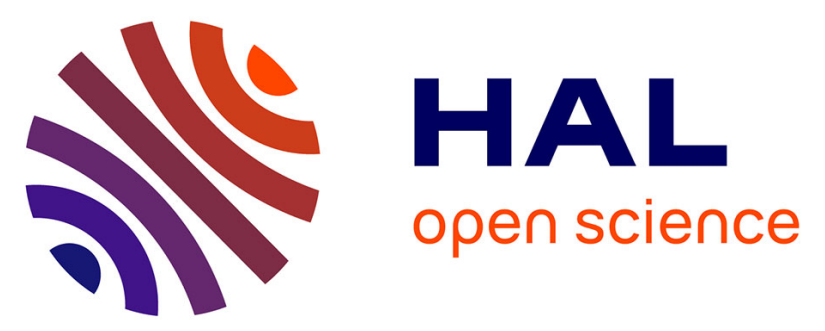

\title{
Green Virtual Business Network for Managing and Reusing Waste Between Partner Organizations
}

\author{
Ahm Shamsuzzoha, Petri Helo, Maqsood Sandhu
}

\section{To cite this version:}

Ahm Shamsuzzoha, Petri Helo, Maqsood Sandhu. Green Virtual Business Network for Managing and Reusing Waste Between Partner Organizations. 17th Working Conference on Virtual Enterprises (PRO-VE), Oct 2016, Porto, Portugal. pp.639-651, 10.1007/978-3-319-45390-3_55 . hal-01614607

\section{HAL Id: hal-01614607 \\ https://hal.inria.fr/hal-01614607}

Submitted on 11 Oct 2017

HAL is a multi-disciplinary open access archive for the deposit and dissemination of scientific research documents, whether they are published or not. The documents may come from teaching and research institutions in France or abroad, or from public or private research centers.
L'archive ouverte pluridisciplinaire HAL, est destinée au dépôt et à la diffusion de documents scientifiques de niveau recherche, publiés ou non, émanant des établissements d'enseignement et de recherche français ou étrangers, des laboratoires publics ou privés. 


\title{
Green Virtual Business Network for Managing and Reusing Waste between Partner Organizations
}

\author{
Ahm Shamsuzzoha ${ }^{1,2}$, Petri Helo ${ }^{2}$, Maqsood Sandhu ${ }^{3}$ \\ ${ }^{1}$ Department of Mechanical and Industrial Engineering, Sultan Qaboos University, PO \\ BOX 33, Post Code 123, Oman, ahsh@squ.edu.om \\ 2 Department of Production, University of Vaasa, PO BOX 700, FI-65101, Finland, \\ \{ahm.shamsuzzoha, petri.helo\}@uwasa.fi \\ ${ }^{3}$ Department of Business Administration, United Arab Emirates University, Al Ain, UAE, \\ maqsoods@uaeu.ac.ae
}

\begin{abstract}
Today, industry is under intense pressure to stay competitive in market segment with limited resources. To withstand such challenges manufacturing organizations need to be collaborative. This collaboration not only benefits many aspects in their daily businesses but contributes other aspects like waste management. In this research, especial focus is given on managing industrial wastes through recycling and reuse between partner organizations as resources within a business network. This concept turns out mutual benefits between partners and managing Eco-friendly business environment based on substituting a new resource by an undervalued resource such as waste. This paper also presents a modelling approach for industrial wastes management within business network, which intends to support the identification of wastes substitution opportunities.
\end{abstract}

Keywords: Business network, waste reuse, industrial ecology, sustainable environment.

\section{Introduction}

The green virtual business network is an environment where companies cooperate with each other for achieving mutual benefits. Such network can be built both physically collocated and virtually distributed regionally or globally. The objective of either form of network is to share resources and expertise within the networked partners under mutual trust. The trust plays the main role to be successful of such networks.

There are various forms and formats of business network with different goals. From literature, it is noticed that most of the business network is mainly focused on developing collaborative products and/or services to gain competitive power over competitors $[1,2]$. However, little or no research is done so far with the issue of managing waste collaborate within the green virtual business network. With the view to fulfill such objective this is concentrated on managing industrial waste through 
forming and executing collaborative business network. The objective of this research can be categorized as follows:

(1) To propose a methodology to support formation and execution of a business network for mutual benefits

(2) To investigate the possibility to managing wastes within collaborative partners

(3) To promote environmental sustainability through green virtual business network

The paper is structured as follows: Section 3 illustrates relevant literature in the proposed field, while Section 3 highlights the research methodology. Section 4 concentrates to demonstrate the life cycle of business collaboration. Brief explanation of industrial waste is outlined in Section 5, whereas; Section 6 states the techniques of collaborative waste management in industry. A framework of networked waste management is illustrated in Section 7, while, mapping of waste management between companies are defined along with mathematical model to calculate the waste-resource analysis within a business network in stated in Section 8. This research is concluded with future research directions in Section 9.

\section{Literature Review}

Today's emerging concept of circular economy motivates global companies to be sustainable in production process and innovation [1]. To achieve sustainability within manufacturing companies need to focus various perspectives. Waste reduction or make the waste reusable as resource is one of an important way. This waste reuse as resource can be done within individual companies or group of companies forming a virtual business network. This kind of network can be termed as green virtual business network [15].

Formation of green virtual business network to improve customer services is a growing trend between companies $[15,16]$. This trend is helping today's business domain in various ways to be competitive in the market segment $[1,2]$.

Managing waste as a result from industrial operations is nowadays is a huge environmental concern. Manufacturing companies are forced by rules to obey global environmental regulations [3, 4]. It is therefore become an obligation for companies to invest resources to manage or treat their waste properly. However, often it becomes difficult for companies to manage waste individually but it asks for cooperation with other companies, which motivates the company to form a business network. This network not only gives added business benefits but also support to manage each other's waste cooperatively.

The application of business network to manage waste is not widely analyzed and found in the literature $[5,14,16,17,18]$. Most of the networks are confined with to achieve business benefits through developing products or processes through collaboration and not management of wastes. This research gaps is identified from 
literature survey and this research presented a guidelines and aspects to manage industrial waste collaboratively.

\section{Research Methodology}

The methodology of this research is highlighted with various stages as displayed in Figure 2. From Figure 1 it is noticed that the first step in the methodology is to identify the problem specification, which is followed by developing the green virtual business network based on the specified problem. When the green virtual business network is formed, in the next available stage of the methodology is to collect necessary data from the case companies within the virtual business network. Initially, five case companies were selected based on their products, whose by-products or wastes can be used between each other as potential resources after necessary treatments. Necessary wastes data were collected through physical visits to the selected case companies' premises, which were mostly historical records from the companies. All the collected data will be analyzed based on its suitability to solve the identified problem.

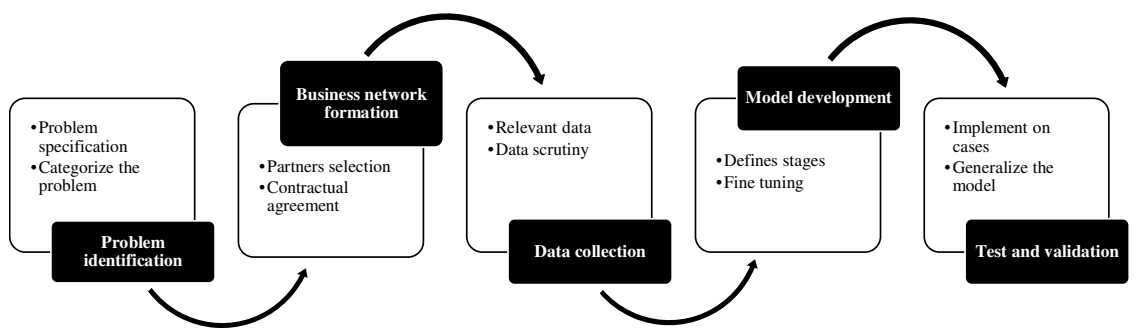

Fig. 1. Stages within research methodology

At the third stage, a model will be developed which is basically a problem solving framework defining each stages how to solve the identified problem. This model will then be tested and validated through implementing it to solve real life case examples. If the model is validated successfully, a generic theory will be proposed to be used to solve specific problem.

\section{Virtual Business Network for Mutual Benefits}

The concept of virtual business network comes from the theme where manufacturing companies are formed through the implementation of information and communication technology (ICT). This ICT framework supports the selection of partners, formation of the partnership network, communication between partner organizations and execution of the collaborative network $[6,7]$. 
A leading partner known as 'Initiator Company', after rigorous market survey, starts this business network after identifying business opportunities. After identifying the business opportunities, the initiating partner company looks for the possible partner organizations within similar business domain. When the partners are selected based on predefined criterions, an agreement is signed between the partner companies, where each of the partner agreed on the specific guidelines to continue this network until the business objectives are fulfilled.

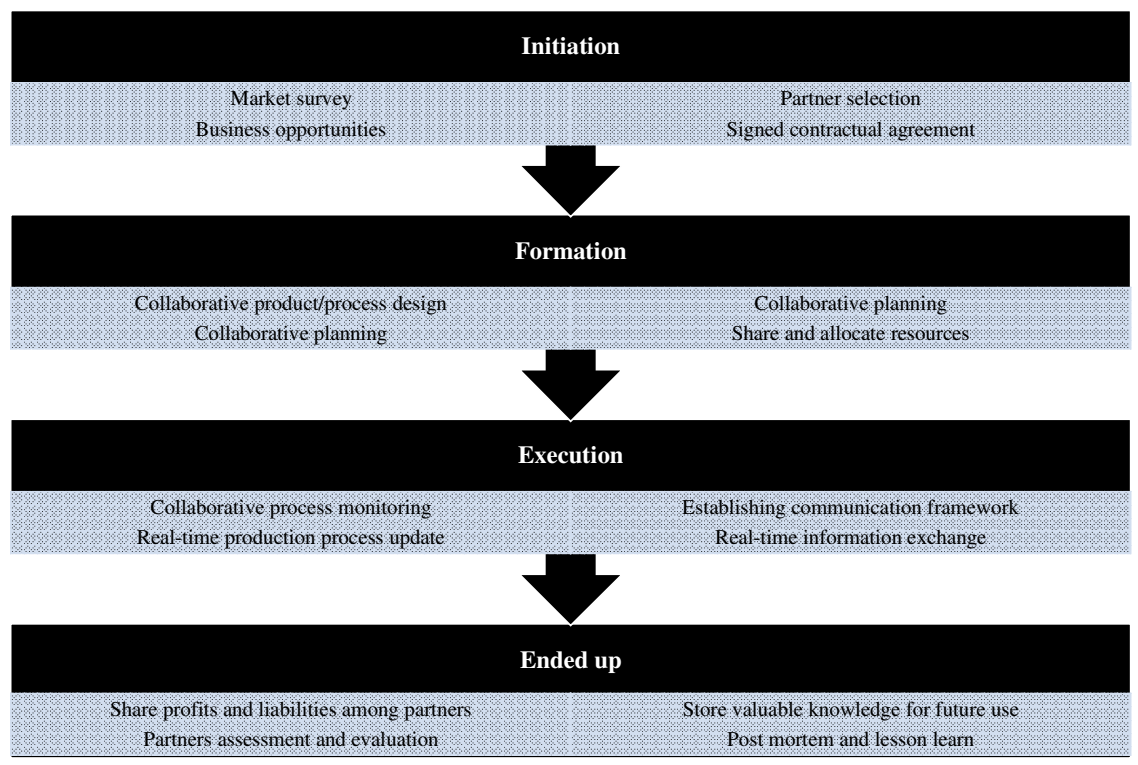

Fig. 2. Life cycle of virtual business network

The next step after signing the agreement is to start designing and developing the product or services based on the pre-identified business opportunities. The product or service design stages are iterated within the partner organizations before finalize it. At this phase, necessary planning and scheduling are done depending on the resources availability within the networked partners.

A communication framework is developed after signing the contractual agreement to continue the network in order to get real-time information from each partner organization. This framework is critical for executing the network efficiently. It ensures on time status of the collaborative product and/or services. This virtual network is dissolved after the product is manufactured and sales in the market successfully. At the final phase, all the liabilities and profits are shared among the partners depending on the agreed contract as signed at the beginning of the network. Complete lifecycle for the virtual business network can be seen in Figure 2.

Similar steps can be followed to form and execute the green virtual business network. In case of green virtual business network, only the business objectives will be difference, which are mainly concentrating to exchange and reuse of wastes as possible resources among partner organizations for mutual benefits. 


\section{Industrial Waste: Managing Environment for Sustainability}

Waste is defined as any material, byproduct or energy that is generally considers as a valueless. Wherever, if there are human activities involved, there will be a waste. Waste can be divided into many categories such as industrial waste, electronic waste, municipal solid waste, health care waste, etc. Industrial waste can be defined as the output of any manufacturing process that is considered to retain no value. Industrial waste can be in three formats: energy, water and material.

The proper definition of waste management is the act of managing the waste from its beginning until its disposal and in each step of the production process asks how to control, modify and eliminate the process in order to reduce waste generations. The waste can also be considered as resource or food for other sector. The waste management is based on the notion of capturing all the missed values in all of the waste flows and can be treated in smart and innovative ways. In addition to, waste management is defined as minimizing the risks of waste to all society, not shifting to other sectors $[8,9]$. There are many technologies used in waste management. Table 1 shows the different waste management techniques and their descriptions.

Table 1. Available waste management techniques

\begin{tabular}{|c|c|}
\hline $\begin{array}{c}\text { Waste } \\
\text { management } \\
\text { techniques }\end{array}$ & Description \\
\hline $\begin{array}{l}\text { Storage } \\
\text { facility }\end{array}$ & $\begin{array}{l}\text { Storage facility can be defined as the holding of waste materials that prior } \\
\text { to use, transport, recycling treatment, or disposal (Schumacher, 1988). }\end{array}$ \\
\hline Recycle & $\begin{array}{l}\text { Recycling of waste results from proper valuable treatment of waste, which } \\
\text { is not harmful for human or environment. }\end{array}$ \\
\hline Reuse & $\begin{array}{l}\text { Reusing and recovery of the waste are part of recycling and make the waste } \\
\text { a valuable resource. }\end{array}$ \\
\hline Recover & Recover defines to use of waste by repair it to make it usable. \\
\hline Exchange & $\begin{array}{l}\text { Exchanging waste is mainly a reusing function; where different facilities } \\
\text { are involved by matching one industry's output to other industry's input. }\end{array}$ \\
\hline $\begin{array}{l}\text { Minimization } \\
\text { /reduction }\end{array}$ & $\begin{array}{l}\text { In minimization/reduction, efforts are made to minimize the production of } \\
\text { waste through various approaches such as process/raw material } \\
\text { substitution, efficient prevention and modification of industrial wastes, etc. }\end{array}$ \\
\hline Treatment & $\begin{array}{l}\text { Changing the chemical and physical of waste in order to reduce its volume } \\
\text { and render its hazard. }\end{array}$ \\
\hline Disposal & $\begin{array}{l}\text { Is the last technology in management of the waste if the upper ones is not } \\
\text { applicable in this technology the waste is stored for a long periods in a } \\
\text { landfills to isolate it from the surrounding environment. }\end{array}$ \\
\hline
\end{tabular}




\section{Collaborative Waste Management: Potential for Mutual Resources}

It is become important for manufacturing companies to abide by environmental rules and regulations. To respect such rules and regulations manufacturing managers need to adopt various strategies to limit the impact of their operations and products on the natural environment. Manufacturing companies produces huge amount of wastes that affects environment if they are not treated or recycled properly. These wastes need to be managed effectively and efficiently for the benefits of companies themselves, diverse stakeholder groups, including end-customers, industrial customers, suppliers and financial institutions [3].

Manufacturing companies are evolved with various environmental aspects such green purchasing [4], reverse logistics [9], product stewardship [10], etc. All such activities involve varying degree of interaction with the companies in manufacturing domain from suppliers to end customers. The limited knowledge and understanding of individual companies for environmental awareness has hampered the development of widely accepted model or framework to manage costly environment. Although, several business networking or collaboration can be found in the literature, however, few researches found on collaborative management of environment.

The level of wastes as manufacturing companies are producing in their daily production lines often become cumbersome and unmanageable by individual company's efforts. In such challenging situation, combined effort to manage such wastes can offer companies economic benefits as well. In collaborative way, wastes can be treated internally by the knowledge and expertise from partner companies or can be treated in a common place for mutual efforts. The way of waste treatment may be varied from company to company but the objective will be same to get benefit from it. There are some ways already exists, where partner companies can manage their wastes in collaboration. Some of the ways to waste management is highlighted in Table 2.

From Table 2 it is noticed that the waste can be managed through several organizational forms and processes. In case of organizational forms, such as industrial symbiosis, eco-industrial parks, etc., wastes are managed through collaboration and such synergistic possibilities are offered by geographic proximity. Whereas, in case of processes, such as recycling, reuse, etc., wastes are treated depending on the wastes natures. For instance, in waste recycling the process can be up-cycling or downcycling and for reuse case, it can be direct reuse or use as second-hand, which is dependent on the waste nature. 
Table 2. Various ways to collaborative waste management

\begin{tabular}{|l|l|}
\hline \multicolumn{1}{|c|}{$\begin{array}{c}\text { Collaborative } \\
\text { waste management }\end{array}$} & \multicolumn{1}{c|}{ Brief description } \\
\hline $\begin{array}{l}\text { Industrial symbiosis } \\
{[11,12]}\end{array}$ & $\begin{array}{l}\text { It is associated with the concept to utilize each other's by-products } \\
\text { and otherwise share resources within the business collaboration. }\end{array}$ \\
\hline $\begin{array}{l}\text { Industrial eco-park } \\
{[13]}\end{array}$ & $\begin{array}{l}\text { With this concept business partners cooperate with each other and } \\
\text { with the local community to reduce waste and pollution by } \\
\text { efficiently sharing resources. }\end{array}$ \\
\hline $\begin{array}{l}\text { Waste-to-feed } \\
\text { exchange }\end{array}$ & $\begin{array}{l}\text { In this concept, one company's by products are used as resources } \\
\text { to other company through mutual agreement through forming the } \\
\text { business network. }\end{array}$ \\
\hline $\begin{array}{l}\text { Business ecosystem } \\
{[14]}\end{array}$ & $\begin{array}{l}\text { In this business domain, collaborative partners shares both } \\
\text { resources as well as wastes between each other to stay environment } \\
\text { friendly. }\end{array}$ \\
\hline Systematic approach & $\begin{array}{l}\text { In this approach, collaborative partners take the form of waste } \\
\text { cascading, shared logistics for building green retrofits and new } \\
\text { strategies in existing industrial developments. }\end{array}$ \\
\hline Waste-to-energy & $\begin{array}{l}\text { At this concept, collaborative partners attract complementary } \\
\text { businesses to use the waste to produce energy between each other } \\
\text { that could benefit from eco-industrial strategies. }\end{array}$ \\
\hline $\begin{array}{l}\text { Eco-industrial park } \\
{[13,15]}\end{array}$ & $\begin{array}{l}\text { In this concept, partner companies are collocated in a certain } \\
\text { geographic location to participate in the industrial waste } \\
\text { management system with the objective to reduce environmental } \\
\text { impact. }\end{array}$ \\
\hline
\end{tabular}

\section{A Framework for Collaborative Waste Management: Green Virtual Business Network View}

Although, several researches are done on virtual business networks successes and limitations but limited researches are done on green virtual networks directly involved with managing industrial wastes $[16,17]$. Several IT-based tools are available to manage waste in general but due to cost and complexity they may not be suitable for many companies, especially small and medium size enterprises (SMEs) [18, 19]. Most of the individual company treats its by-products or wastes separately, which may not be very cost effective and efficient. In such circumstances, companies (SMEs) can collaborate by forming a green virtual business network with the objective to monitor and manage their wastes and look for the possibilities to exchange or recycletreuse of wastes as resources among each other.

Green virtual business network can play an important role in managing and reusing/recycling industrial waste among the network chain. This kind of network can be defined specifically to focus on inter-organizational goal setting, shared environmental planning and to work together to reduce environmental damage through wastes treatment processes like industrial ecology, industrial symbiosis, reuse/recycling/discard, etc. These practices with the objective to reduce environmental impact can be directed either upstream toward partner organizations or downstream toward customers. The upstream practices are closely linked with 
process-based performance monitoring, management, while downstream practices are related with product-based performance monitoring, and management.

To maintain industrial ecology, it is necessary to build collaborative effort within companies. Such collaborative effort supports to enhance waste management through recycling, reuse and discard. In order to fulfill such objectives, companies need to follow a framework that guidelines companies step-by-step to manage their harmful wastes. The framework can be based on both physical network within companies and/or green virtual network. This kind of network helps to utilize each other's byproducts, otherwise, share as resources into economic products among the partner organizations.

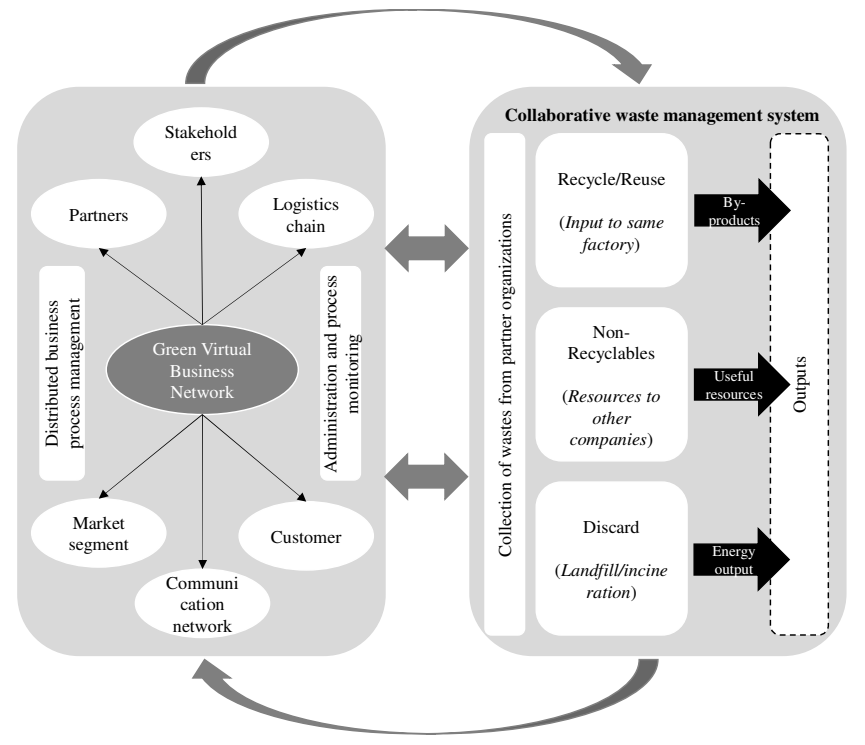

Fig. 3. Collaborative waste management framework

A framework for green virtual business network to manage waste is displayed in Figure 3. From Figure 3 it is noticed that there is an iterative relationship between the business network and the waste management system. The basic functionally of the business network is to manage distributed business processes, which are supported by necessary administration and process monitoring. The green virtual business network is tightly coupled with partners, stakeholders, logistics chain, market segment, communication network and customer as highlighted in Figure 3.

In addition to managing the business processes, the green virtual business network is interacting with the collaborative waste management system. This waste management system has three formats such as recycle/reuse, non-recyclables and discard. In the recycle/reuse phase, collected wastes from the partner companies are treated and the by-products are used internally. In the non-recyclable phase, the collected wastes are used as possible resources within the network partner organizations. In the discard phase, recyclable and non-recyclable wastes are used as 
landfills/incineration as depicted in Figure 3. The framework as outlined in this research can be successfully implemented to manage collaborative industrial wastes and keep the costly environment clean for human being.

\section{Networked Waste Management: Illustrative Business Cases}

(a) Mapping of waste management among the green virtual business network

As explained earlier, the networked waste management is an idea, where one company's waste within a business network can be a useful resource for other company. This concept contributes to the input-output matching approaches by including different types of resource substitutions. It can be demonstrated as the modelling approach, which is used for identifying potential waste, which is considered as output from an industry, and use as input resource to other industry. This type of waste management technique can be successfully implemented in a green virtual business network, where the collaboration starts after identifying business opportunity to exchange waste between partners.

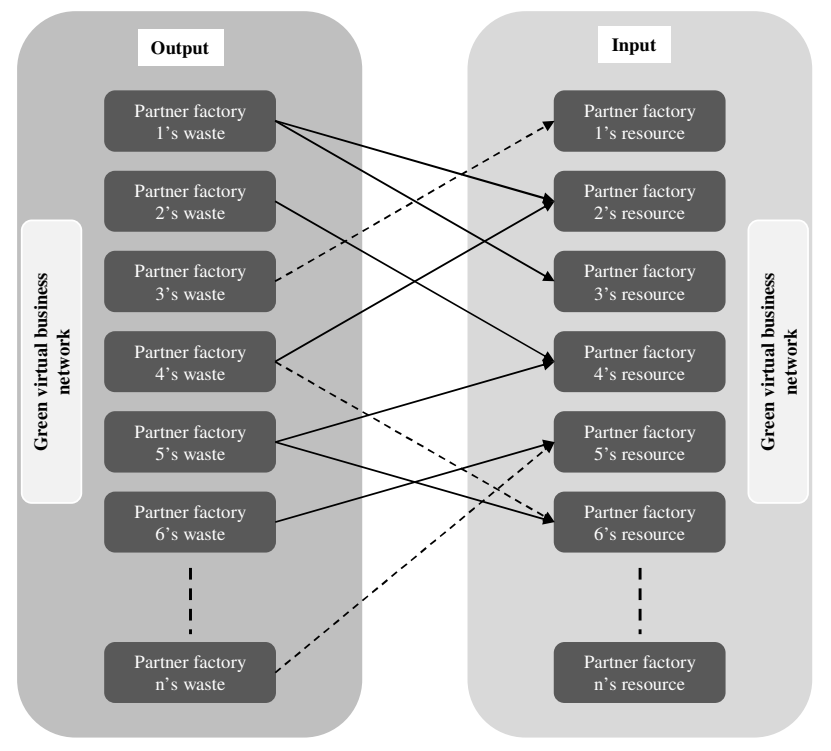

Fig. 4. Mapping of waste reuse within a green virtual business network

Figure 4 demonstrates an idea of waste management through mapping among collaborative partner organizations within a business network. As seen from Figure 4, the wastes from one or more partner organizations can be successfully used as resources for the other company or companies depending on their matching and suitability. From Figure 4, it can also be noticed that all the companies within the 
business network may not exchange wastes among each other due to unsuitable, or individual company might be specialized to treat its wastes for internal use. For instance, from Figure 4 it is seen partner factory 3's waste may be or may not be used or suitable as an input resource for partner factory one. Most of the cases, some wastes might be needed some kinds of processing before using them as resources by the other partners companies. This collaboration practices support network partners to minimize and reuse their waste effectively and efficiently and promote to maintain environmental sustainability.

Often such wastes might need to be processed within the network partners to them useful resources. Such processes can be incineration, waste symbiosis, departed, sorting, recycling, etc. In case of the reprocessing needs, individual partner organization or group of similar kind of waste producing partners can collaborate with each other with their skills and expertise to treat such wastes useful. There should be balanced between supply wastes and resources demand. In case of overstocked wastes can be discarded by the partners in an environmental friendly ways.

(b) Mathematical model of collaborative waste management

The exchange of waste and resource is of course depends of the demand-supply relationships between the companies. Each of the waste to be used as resource has a quantity. The amount of supply of waste cannot exceed the available demand as resource. In case of mismatch between supply and demand, priority will be given on the first come first serve basis. Even waste exchange policy can be formulated based on the evaluation on which waste demand can give better use to the waste. This waste supply and resource demand can be presented as of a mathematical model as follows (adapted from Hein et al., 2015):

$$
W S_{i j} \geq \sum_{j=1}^{n} w s_{i j}
$$

Where, $w s_{i j}$ is a waste supply $i$ that meets a resource demand $j$. In any situation, the sum of $w s_{i j}$ cannot exceed the total available waste supply $W S_{i j}$. In addition to that, the sum of waste supplies $w s_{i j}$ for a resource demand $R D j$ has to be equal or less than the resource demand. This relationship can be stated as:

$$
R D_{j} \geq \sum_{i=1}^{m} c_{\mathrm{i}} w s_{i j}
$$

Where, ci is a conversion factor for treating up and downstream substitutes. For example, if the resource demand of an organization is equal to waste supply from another organization and it is used properly as resource then the $c_{j}$ factor will be equal to 1 . This conversion factor allows for calculating the summation of new resources that are substituted. Three criterions can be used for evaluating the waste-resource conversion within green virtual business network:

- Maximize the quantity of substituted new resources $w s_{i j}$

- Maximize net profit by substituting earn revenue $E R_{i j}$ minus operating cost $O C_{i j}$ for a match $W S_{i j}$

- Minimize capital investment $C I_{i j}$ for a technology to transfer $w s_{i j}$

The cost of capital investment can be $C I_{i j}$ due to cost incurred to transportation cost to transfer waste from one factory to another one, waste conversion or recycling cost 
to make it useable resource for other factory if needed, cost for $\mathrm{CO}_{2}$ emission process if there is any, etc. In order to calculate cost-revenue balance sheet, it is useful to formulate multi-objective optimization problem with the objective functions as of:

$$
\begin{aligned}
& \sum_{i=1}^{m} \sum_{j=1}^{n} c_{\mathrm{i}} w s_{i j}=\text { maximum } \\
& \sum_{i=1}^{m} \sum_{j=1}^{n}\left(E R i j-O C_{i j}\right)=\text { maximum } \\
& \sum_{i=1}^{m} \sum_{j=1}^{n} C I_{i j}=\text { minimum }
\end{aligned}
$$

Subject to the constraints:

and

$$
\sum_{j=1}^{n} \mathrm{Ws}_{\mathrm{ij}}-\mathrm{WS}_{\mathrm{i}} \leq 0
$$

$$
w s_{i j} \geq 0
$$

The waste data from the case organizations are to be analyzed following the abovementioned mathematical model and multi-objective optimization in order to make the waste management process economically feasible for the organizations within a business network. The analysis will be done in a manner as highlighted in Table 3.

Table 3. Exchange of waste-resource with quantity within a collaborative business network

\begin{tabular}{|l|l|l|l|}
\hline Waste supplier & $\begin{array}{c}\text { Waste receiver as } \\
\text { a resource }\end{array}$ & Resource name & Quantity \\
\hline Organization 1 & Organization 3 & TBA & TBA \\
\hline Organization 2 & Organization 1 & TBA & TBA \\
\hline Organization 3 & Organization 2 & TBA & TBA \\
\hline Organization ...n & Organization ...m & TBA & TBA \\
\hline
\end{tabular}

Based on the predefined objective functions total amount of waste from one organization as the replacement of resource for other organization, capital investment and net profit can be calculated and summed up as presented in Table 4 as sample. It is noted that only profitable waste-resource exchange (feasible solutions) will be allowed and non-profitable scenarios will be discarded from consideration.

Table 4. Various objective functions and values from collaborative waste management

\begin{tabular}{|l|c|}
\hline \multicolumn{1}{|c|}{ Objective functions } & \multicolumn{1}{|c|}{$\begin{array}{c}\text { Values from multi-objective } \\
\text { optimization model }\end{array}$} \\
\hline $\begin{array}{l}\text { New resources substituted from available } \\
\text { waste }\end{array}$ & TBA \\
\hline Capital investment $\left(C I_{i j}\right)$ & TBA \\
\hline Net profit margin $\left(E R_{i j}-O C_{i j}\right)$ & TBA \\
\hline
\end{tabular}


In this research, in total 10 companies within a business network will be analyzed. Relevant data related to waste for five case companies are already collected. After collecting remaining five companies' data, necessary cross mapping of waste exchange will be done. Eventually, supply-demand balance between waste-resource will be done in association with economic benefits from this approach too.

\section{Conclusions and Future Research Avenues}

The objective of this research is to manage waste, especially industrial wastes properly and to contribute to maintaining environmental sustainability. In this study, it is proposed that waste management in a more collaborative way can be beneficial for partners' organizations within a virtual business network. Of course, such network can be within an industrial district or park or can be formed globally, where contractual agreement is done through mutual trust. This networking philosophy is existing in different format such as virtual factory, virtual organization, industrial ecosystem, etc. General trend to forming such collaborative networks is to gain business benefits after identifying market opportunities.

The collaborative network as proposed in this research is also gaining mutual benefit for not only dominating the market segment by the collaborative partners, but also maintaining environmental sustainability through managing wastes. This waste management is done through environmental collaboration with partner organizations contributed to a relatively broad range of competitive benefits. Collaboration with partner organizations on environmental issue is linked to improvement in three traditional dimensions of organizations performance such as quality, delivery and flexibility in addition to environmental performance.

Management of waste in a collaborative way allows greater control over contextual and operational factors of the partner organizations in the network. It allows partners to interact between each other's in order to joint environmental planning and shared environmental know-how or knowledge. As such, any monitoring or control elements usually included in green production process within the business collaborators with the view to minimize wastes as much as possible.

In this research study, a framework is presented highlighting the possibility to manage collaborative waste efficiently. Five case companies within a business network's waste data is under study. In the coming months, more partner organizations waste data will be collected to analyze for possible cross mapping of waste-resource exchange within the partner organizations. This mapping will also be economically analyzed based on multi-objective optimization model as explained in this research. At the end of the research, the supply-demand analysis will be done based on the available waste (supply) with the required resource (demand). In future, in addition to exchange of waste between partners, the collaboration-performance relationship will be studied with the view for better performing green virtual business network. 


\section{References}

1. Romero, D. and Molina, A. Green Virtual Enterprise Breeding Environments: A Sustainable Industrial Development Model for a Circular Economy. Camarinha-Matos, L.M., Xu, L. and Afsarmanesh, H. (Eds.), Collaborative Networks in the Internet of Services $-13^{\text {th }}$ IFIP WG 5.5 Working Conference on Virtual Enterprises, PRO-VE 2012. Springer Berlin Heidelberg, 380, 427-436 (2012).

2. Camarinha-Matos, L.M., Afsarmanesh, H., Galeano, N., Molina, A.: Collaborative Networked Organizations - Concepts and Practice in Manufacturing Enterprises. Computers \& Industrial Engineering, vol. 57, no. 1, pp. 46-60, (2009)

3. Henriques, I. and Sadorsky, P. the Relationship Between Environmental Commitment and Managerial Perceptions of Stakeholder Importance. Acad. Mangt. J. 42(1), 87-99 (1999)

4. Zsidisin, G.A. and Siferd, S.P.: Environmental Purchasing: a Framework for Theory Development. Euro. J. Purchase. \& Sup. Mangt. 7(1), 61-73 (2001)1.

5. Hein, A.M., Jankovic, M., Farel, R., Lei, S. and yannou, B.: Modelling Industrial Symbiosis using Design Structure Matrices. Int. conf. Depenedency Structuer Matrix, Texas, USA, 4-6 November (2015)

6. Romero, D., Molina, A.: VO Breeding Environments \& Virtual Organizations Integral Business Process Management Framework. Information Systems Frontiers, vol. 11, no. 5, pp. 569-597 (2009)

7. Camarinha-Matos, L.M., Afsarmanesh, H.: A Comprehensive Modeling Framework for Collaborative Networked Organizations. Journal of Intelligent Manufacturing, vol. 18, no. 5, pp. 529-542 (2007)

8. Goldman, B. A. (1986). Hazardous Waste Management: Reducing The Risk. Washington: Island Press.

9. Prahinski, C. and Kocabasoglu, C. Emprical Research Opportunities in Reverse Supply Chain. Omega. 34(6), 519-532 (2006)

10. Snir, E.M. Liability as a Catalyst for Product Stewardship. Prod. Plan. Control. 10(2), 190$206(2001)$

11. Chertow, M.R. Industrial Symbiosis: Literature and Taxonomy. Annual Rev. Energy. and Env. 25, 313-337 (2000).

12. Chertow, M.R. "Uncovering” Industrial Symbiosis. J. of Ind. Ecology. 11(1), 11-30 (2007).

13. Lowe, E.A. Creating By-Product Resource Exchanges: Strategies for Eco-Industrial Parks. J. Clener Prod. 5(1-2), 57-65 (1997).

14. Gossain, S. and Kandiah, G. Reinventing Value: The New Business Ecosystem. Strat. \& Leadership. 26(5), 28-33 (1998).

15. Chertow, M.R. The Eco-industrial Park Model Reconsidered. J. of Ind. Ecology, 2(3), 8-10 (1998).

16. Romero, D. and Molina, A. Green Virtual Enterprise Breeding Environments Reference Framework. Camarinha-Matos, L.M., Pereira-Klen, A. and Afsarmanesh, H. (Eds.), Adaptation and Value Creating Collaborative Networks - 12 ${ }^{\text {th }}$ IFIP WG 5.5 Working Conference on Virtual Enterprises, PRO-VE 2011. Sao Paulo, Brazil, Springer Berlin Heidelberg, 362, 545-555 (2011).

17. Cherubini, F., Bargigli, S. and Ulgiati, S. Life Cycle Assessment (LCA) of Waste Management Strategies: Landfilling, Sorting Plant and Incineration. Energy. 34(12), 21162123 (2009). 
18. Sustainable Solid Waste Management: An Integrated Approach for Asian Countries. Waste Manage. 29(4), 1438-1448. 